\title{
Theology and the arts: The Corona crisis
}

John L. Bell

Rev Dr John Bell is a minister in the Church of Scotland, a member and employee of the Iona Community, a hymnwriter and occasional broadcaster.

\section{Palliative care}

My starting point as regards this paper is palliative care. I think there is too much of it. I'm not referring to the medical assistance and pastoral and spiritual support given to people who are dying. I'm referring to what seems like a super-abundance of saccharine piety which churches have been offering to people in response to the pandemic which is unilaterally affecting the world.

Of course, when faced with a virus which is largely indiscriminate in the range of people affected, it is right that the church should offer that kind of consolation which is called the 'comfort of religion'. People need to know God's love mediated through sensitive care, well-chosen words, Scripture, and the sacraments. Believers need to be reminded that nothing in the heights or the depths can separate them from the love of God which is in Christ Jesus.

With all of this I concur, and in a small way I have contributed to this pastoral ministry in both corporate and individual circumstances. Here is one such text:

1. Though hope desert my heart, though strangeness fills my soul, though truth torment my troubled mind, you have been here before. 
2. Though confidence run dry, though weary flesh is sore, though conversation bear no fruit, you have been here before.

3. There is no threatening place, no trial I could know which has not known your presence first: you have been here before.

4. In Christ who, on the cross, felt all our hurt and more, and cried in deep abandonment, you have been here before.

5. I will not dread the dark, the fate beyond control, nor fear what reigns in frightening things: you will be there before.

Copyright (c) 2005 Wild Goose Resource Group, Iona Community

So I am not exempting myself from pastoral engagement, but I do not believe that this is all that people of faith have to offer. I want to suggest three possible trajectories:

1. A vocabulary for lament

2. A theological critique of the pandemic

3. A re-imagining of the future

\section{A vocabulary for lament}

I received an email two weeks ago from a church musician who was inquiring as to what people might sing which would allow for an articulation of their feelings of anxiety and distress. There wasn't anything which immediately came to her mind. It was as if either that kind of expression went against the grain of Christian positivism, or we didn't have a vocabulary to express it. 


\section{Hair}

It took me back to an evening, now at sixteen years ago in Minneapolis when I treated three younger colleagues to a theatrical event which I had seen before they were conceived. The name of the show was Hair. I saw it when I was twenty-one. I remembered and can still sing some of its short songs, I remember its multi-cultured cast, their psychedelic clothes and 30 seconds of full nudity on stage.

What I had forgotten was that this was a protest musical. The central character was a boy who decided not to flee the draft by going to Canada, but to leave his commune and be drafted to Vietnam, where he was killed.

It came to the end of the performance. The audience rose to cheer an excellent production and cast. And then one of the minor characters came to the apron of the stage and motioned for silence. He said,

We are so glad to be playing to you tonight in Minneapolis. But just today, we discovered that the first female in the military to be killed in the current Gulf War came from this city. We also discovered that there is a fund established in her memory. The money from it is going to look after Iraqi children who have been orphaned or wounded by allied bombing. So after each performance we are going to stand outside with buckets as you leave. And if you wish you can make a donation to this fund to help these desolate children in Iraq.

And then from this adult audience came the sound of weeping. Grown men weeping. This was at a time when the Patriot Act forbade public criticism of the government, and when songs by a girl band called the Dixie Chicks had been pulled from public performance.

This anti-Vietnam musical which protested against the pursuit of death had voiced what no contemporary musical in 2004 would have been allowed to do, and in donating to a fund set up in memory of a local girl who had been killed in Iraq, people were making perhaps the first tangible sign of their discontent with a war now in its second of eight years.

\section{Protest and lament - the '60s and South Africa and spirituals}

In the ' 60 s and ' 70 s there was a vocabulary given the public by its artists 
to articulate their rawness of feeling ... not just songs which would say things will get better by and by ... anthems like "Blowing in the Wind".

Protest and lament are very old traditions. They were important in the struggle against apartheid in South Africa, the voices of a people who sang out their belief that things had to change and sang out their pain. The national anthem of those under apartheid was not "Nkosi Sikelel' iAfrika" - that was a pan-African song. Now the anthem of those who suffered was much shorter:

Senzenina? - What have we done?

Sono sethu? - What is our sin?

It didn't come from a Hollywood composer; it came from the Bible. When David was being pursued by Saul he asks:

What have I done? What is my sin? (1 Sam 20:1)

I have a fascination for African-American spirituals, because they - often with few words and even fewer notes - have offered the pain of persecuted people to their God and to each other.

Nobody knows the trouble I've seen,

Nobody knows but Jesus.

Sometimes I'm up, sometimes I'm down;

Oh, yes, Lord.

\section{Psalms}

But, of course, those of us who have some allegiance to the Jewish or Christian traditions shouldn't need to go to Africa or black America for a vocabulary to articulate pain anger, disappointment frustration, victimisation. It's all there in the psalms if only we can see beyond those used primarily for palliative care. Last year I was working on a book about the psalms - not a commentary, but a series of reflections and insights which came from discussing them with a whole range of people.

I was most amazed by how some people took to Psalm 88, the bleakest psalm in the Bible, which has accusations against God, questions to God, and sarcastic remarks about God. Time and again people recognised that it 
offered a vocabulary for people who were stuck for words because life was so hellish and praise songs weren't doing the trick - a girl whose brother had committed suicide, a poor woman in North Glasgow whose life had gone through the mill, a diocese of the Anglican church riven with disagreement. Something in these angry words offered to God allowed for an expression of what polite faith would regard as inadmissible.

There are a fair number of psalms which rail against personal or social injustice. My friend Doug Gay, who is a lecturer at Glasgow University, worked on a singable text of Psalm 52. It's in a collection in the USA, though I doubt if it has often been sung. But were I living in that country now with its multiple troubles I might want to proclaim it:

You cunning liar, why publicise your evil need to harm the good? Your slanderous tongue is razor-sharp, honed to fulfil malicious plans; You love the lie and hate the truth.

May God rise up to pull you down, uproot and sweep you far away. Then may the just look on aghast and mock the one who valued wealth, who trusted riches more than God.

God let me, like a spreading tree, grow as I trust in your sure love. Where loyal servants offer praise within your house, I'll add my voice to glorify your holy name.

Copyright (C 2011 Wild Goose Resource Group, Iona Community

I have a profound conviction that whether we are the victims of a global pandemic, or want to intercede for those who are most affected, or whether we want to show solidarity with a persecuted and neglected people, be it Rohingya Muslims exiled from Myanmar or the black community in the USA which is the victim of three plagues - Covid-19, unemployment and white racism - we can keep hope alive not just by singing the praise of 
God, but also by articulating the pain of the people. Indeed I wonder if we have any right to shout 'Hallelujah!' if we have never found occasion to ask, 'How long?'

\section{A theological critique of the pandemic}

I am interested in what theological understandings we share about the global pandemic, because I have not heard very much articulated. I suppose there are two polarities which, at least to me are equally unattractive: sin-sniffing and escapism.

\section{Sin-sniffing and escapism}

At the one end of the spectrum we have the sin-sniffers, people who enjoy identifying iniquity in the same way as some individuals enjoy bad health. 'It all comes down to guilt and sin' is what they would claim. It goes right back to the fall and to the inherited congenital moral malformation called 'original sin'. I imagine that the American evangelist Pat Robertson might be pursuing this line, though I speak under correction.

Exactly what the iniquity is, however, is not identified. To say that the pandemic is caused by sin is wholly insufficient. Is it personal sin or corporate sin? Has it a root, a source, a furtive intention? Or is it the work of the Devil, who - as in the case of Job - has been given free rein by God to visit hardship on innocent people to test their fidelity?

At the other end of the theological, liturgical and emotional spectra, are those who would claim that it's best not to dwell on it, as we can't explain it. Much better to pray harder, trust more and sing with ever greater enthusiasm. God has promised to shield his own and God keeps his promise. This is a very attractive mindset as long as you don't fall prey to Covid-19. And on both sides of the Atlantic there have been religious snake-oil salesmen offering their own brand of this kind of spiritual panacea. I find neither of these caricatured extremes satisfying. But what do you say to explain what is unjust and all-pervasive?

I want to offer two perspectives which I don't imagine will be popular, but I think they should be rehearsed. These concern finitude and the relationship between humanity and the planet. 


\section{a) Finitude}

What we are dealing with as regards the global pandemic is not just a menacing disease, but our own finitude. Just as some people shy away from engaging with a person who has a mental or physical disability because - if they are honest - they don't know what to say or do, so in the face of a global pandemic we are lost for words and for a fail-safe response. This is not a broken leg which will heal, or a cancer which might respond to chemotherapy. We can't say to people who suspect they have the disease, 'I'm sure you'll be all right' with any certainty. We are confronted with an invisible agent which all the wealth, military might and accrued knowledge of experts has been unable to quickly exterminate or tame.

We are confronted with our own finitude. We are not as gods. And that is easier to say than it is to believe. It is the dilemma of Job which neither his sense of righteousness nor his comforter's conviction regarding sin are able to fathom.

In the West we have sub-consciously believed (though on what basis?) that this current plague shouldn't happen to us.

\section{Hawaii}

Some years ago I was working in Hawaii, in Hilo on the big Island. One day those of us who were not native islanders were taken up to an observation point near the rim of an active volcano. An islander explained that if and when the volcano threatened eruption it was important to establish the likely direction of the lava flow so that people could move out of their houses.

It struck me that if I lived on that island, I wouldn't consider living anywhere apart from the coast, given the possibility of a volcanic eruption, but the islanders didn't think that way - for them risk and uncertainty are givens that you have to live with. For most Western urbanites risk and uncertainty are what we try to avoid.

At the core of this, especially for people of the Judaeo-Christian tradition is a common misreading of Genesis chapter 1 .

In that great creation hymn, there is a constant refrain:

God saw that it was good. 
At the end of the creation cycle the approval rating is higher:

God saw all that he had made, and it was very good. (Gen 1:31)

Good ... but NOT perfect.

It is not that creation has a moral defect, but that it has fault lines - of which the San Andreas fault in California is among the best known. Creation has logical inconsistencies, as when some Australian gum trees burst into flame not for the purpose of extermination, but as a means of germination.

Creation has inexplicable irregularities. The other morning, I listened to an expert on snails talk of how years ago he had been given a snail called Jeremy whose shell coiled to the left and not to the right. He had bred four generations to see if there was genetic transmission of this irregularity to its progeny, but none appeared with a left-coiling shell. There was no explanation.

The nations which believe they are invincible have the most difficulty in dealing with a menacing untameable threat. We know what to do should our country be the object of a trade embargo or invasive enemy surveillance. We can use our power, our ingenuity to deal with this. But we have no immediate defence against the threats to our existence which come from a world which we presume to be perfect and predictable rather than good but prone to casuistry. We have to learn to respect our limitations.

This leads to my second perspective:

\section{b) The relationship between humanity and the Earth}

We will all have heard, based on Scripture, that God has given humanity dominion over the earth but not domination. There is an integrity in creation which is not ours to alter, and so we have to live in a symbiotic relationship with nature.

\section{The Harris Super-quarry Inquiry}

We were alerted to this in Scotland when some years ago a mining conglomerate offered to fell a mountain on the island of Harris and dig a 
huge quarry to extract stone to be shattered into aggregate for road building. I'd love to discuss the issue in detail, but this is not the occasion. What I want to allude to is the government inquiry at which proponents and opponents of the plan presented their cases. Among the opponents were two very different men. One was large and dressed in the robes and headgear of a Canadian First Nations chief. He was Chief Stone Eagle of the Mi'kmaq nation. The other, a much slighter figure, was a native of Harris, a Gaelic speaker and a professor of theology, Donald Macleod. Their testimonies were remarkably similar. Donald Macleod's was the more biblical and one of his stunning observations was that we bond quickly to the assumption that humanity is mandated 'to till the earth' (Gen $2: 15)$. However, Donald pointed out that 'to till' was more commonly rendered in the Hebrew as 'to serve'.

The Pentateuch records that there should be a right relationship between humanity and the planet we live on. The story of Noah has God throw into the sky his bow - which was not initially a symbol of Gay Pride, but of war. God's weapon of mass destruction will never again be used to annihilate the natural world. Humanity does not make a similar covenant with the earth, and so it is the prophets and the poets who use graphic language to alert the human race to how its own existence depends on it living in a complimentary relationship with nature. Thus:

But your wrongdoing has upset nature's order, and your sins have kept away her bounty. (Jer 5:25)

It is your fault that the heavens withhold their moisture and the earth its produce. (Hag 1:10)

The earth lurches like a drunkard [...], the sins of its inhabitants weigh heavy on it, and it falls, to rise no more. (Isa 24:20)

Few theologians have dealt with this intrinsic relationship between humanity and the natural order. I think the first I remember was Paul Tillich in one of his published sermons entitled "Nature, also, mourns for a lost good".

The reason for our gross neglect in this matter is because it's only recently - post the industrial revolution - that nature has begun to 
negatively affect us. And rather than re-establish a proper relationship, we go for mastery rather than servanthood. The agrochemical industry will produce better fertilisers. The pharmaceutical industry will produce better vaccines. Highly commendable, but sticking plasters on a running sore. We need to learn servanthood, not mastery.

\section{A re-imagining of the future}

\section{Malvern and the power of artistic expression}

In 1941, the then Archbishop of York (later of Canterbury) William Temple brought together an assemblage of people in the town of Malvern to discuss the shape of Britain when the war was over. Exact details of the proceedings are not known, it was more of an ideas market than a General Synod, but Temple soon after wrote up a summary of the proceedings. $\mathrm{He}$ shared much of this with William (later Lord) Beveridge, and thereby helped shape what, in Britain, is called the Welfare State - the NHS, maternity and unemployment benefits, pensions, etc.

The people who met with William Temple were not all theologians. They included prestigious people from the more artistic side of the social spectrum including the novelist Dorothy Sayers and the poet and academic T. S. Eliot. It is worth remembering the power of artists and artistry to influence society, especially when in recent years the arts have suffered from underfunding.

During the apartheid era in South Africa, the Market Theatre from Johannesburg travelled the world portraying the face of racial discrimination. No one who saw their productions left unmoved.

In Japan, at one time a country with a small and highly Europhile conservative Christian community, people were taken aback in the midtwentieth century by the audacity of an artist called Sadao Watanabe who dared to depict the biblical environment, its people and even Jesus as Japanese. But gradually his paintings allowed for a sense of Christ incarnate in Japanese culture which all the preaching had not effected.

Just four months ago, I watched a film of a production of Shakespeare's Julius Caesar. There were virtually no props, minimal costume, and played with the audience in the round. It was very different from the proscenium stage production I saw with actors in period costume and RP accents when I was sixteen. Not least because all the actors used the accent 
native to their home region in the United Kingdom and all the actors were female. It revealed the scheming, jealousy and lust for power which an allmale cast could never have done - and very pertinent to the present political situation in the two major English-speaking imperial nations.

The arts have the potential - through words, music, acting, physical movement and concrete depiction of not just capturing what has been, but allowing a glimpse of what might be, because the arts rely not just on rational thinking and proven skill but on imagination.

\section{Imagination}

It is a commodity which is at the centre of all hopeful and progressive human endeavour. It does not just enable books and plays to be written. It encourages scientific research because the imagination does not pose the question 'What happened?', but 'What if?'

It is how battles are won. The rules of war are one thing, but the strategies to take the enemy by surprise are entirely another. One the great strategists in this regard was Nelson Mandela in his endeavour to dismantle apartheid and unite a bitterly divided nation. His biography records how, not long into his presidency, he decided that as one senior citizen, he would pay a courtesy visit to another of his age who was celebrating her birthday. The woman in question was Mevrouw Betsie Verwoerd, the widow of former Prime Minister Hendrik Verwoerd, the architect of apartheid, who transferred it from a theological perspective to a political movement. He had been assassinated 30 years previously.

Why did Mandela, who had been incarcerated by the political regime Verwoerd initiated, go to have a birthday tea with his widow? You can imagine how black widows must have felt who had lost brothers, sons, fathers, husbands because of the apartheid regime. They must have been outraged. But Mandela did that and other highly imaginative symbolic acts because only when he, without words, demonstrated what reconciliation cost and looked like could others catch a glimpse of a different future.

He wasn't the first leader to share food with a perceived enemy woman. Both Elijah and Elisha had done that. It was recorded in the history books, and when Jesus chose to allude to these imaginative prophetic actions in his home synagogue, the congregation turned against him. 


\section{The ally of faith not the enemy}

Imagination is not, as some suspect, the enemy of faith, but the ally. It is what enables the prophets to offer a glimpse of a new day of racial harmony, of peace with and within nature, of weapons being turned into gardening tools.

It is at the heart of Jesus' parables. It is what in these stories both shocks and delights people - that those who work for one hour get as much as those who work for twelve, that a son who has squandered half the family fortune should come home to a feast in his honour, that people who beg or sleep under hedgerows should be invited to a royal banquet in preference to the literati and glitterati.

And, at least in my thinking, it is what is sorely needed while we are still in the grip of the pandemic. So much has changed, so much has altered, and though people yearn to get back to living normally and business as usual, such yearning is tinged with suspicion. Because we now see, in glorious profile that the old normal was abnormal.

Do we want to back to believing that the only people who are important are the high wage earners, while the lowest-paid attendants in care homes, security people and delivery agents have been celebrated for their heroism?

Do we want to go back to the old normal where we believed that our health and social welfare services thoroughly British, when of the first twelve front-line doctors to die from Covid-19, all but one were born in our former colonies?

Do we want to go back to attention being heaped on the medical research where the shots are called sometimes by global pharma, while the most basic form of cheap preventative medicine and behavioural practices are the stuff of the grossly underfunded public health departments?

Do we want to go back to the closure and sale of school playing fields and the underfunding and demotion in importance of the arts in secondary education, despite proof that - as in the case of the Sistema music projects in two Scottish schools - teaching children musical skill benefits their whole educational attainment, encourages cooperation rather than competition, and brings stability to demoralised communities?

Do we want to get back to over-polluted cities, high use of personal motorised transportation and a neglect of the countryside?

Do we want to return to a belief that we are a self-sufficient nation, 
when so much of our industrial base, our food production, our consumer goods are dependent on trade with the very nations we either withdraw from or belittle?

I could go on.

What will deliver us from the new normal being a slimmed-down and stitched-up version of the failed old normal is not, I believe, in the gift of politicians. No politician in any of the world's democracies was elected to deal with a pandemic or post-pandemic world - none of them. Especially so in Britain, where the government represents a hegemony of public schoolboys in long trousers who have proceeded largely through Oxbridge into the law, the banks or political research and hence into Parliament.

It is in this situation, that there needs to be a re-envisioning of the kind of nation we want to be, and creative endeavour as to what will make for the common good. And it is precisely in this endeavour that theology and the arts should join hands. Because theology is concerned, at its most practical, with the transformation of the world to become reshaped according to the contours of the all-inclusive and world-affirming kingdom of God. And the arts are the means by which such thinking, such re-envisioning can take concrete form and permeate the minds of people who may be inured to the predictable chatter of the ruling elite.

At this time when we live in the shadow of racial brutality as evidenced in the killing of George Floyd, people have had recourse to mention the name of Martin Luther King Jr. And doubtless, people will remember his speech at the Lincoln Memorial in which he spoke of a very different America. Drew D. Hansen, a former Rhodes scholar, in his recently republished thesis The Dream, ${ }^{1}$ notes that what we remember is not what King had intended to say. As an intellectual, he had laid out the case against discrimination, he had cited instances, quoted figures - he had fed the minds. And, as a black preacher, he had roused the emotions. All through that speech you can hear people in that huge crowd calling out to him. And having done that he was finished. He walked away from the platform and then heard a female voice, that of Mahalia Jackson, saying, 'Tell them about the dream, Martin. Tell them about the dream.'

So he went back and drawing on some images spoke of a different America, a new day of friendship between the descendants of slaves and of slave owners, different criteria other than skin colour on which children may be judged. It was not logic. It was not emotion. It was divine imagination - that is what propelled people to believe in and work for a 
future different from the past.

$* * * * * * * * * * * * * * * * * * * *$

Some day sculptors will erect statues not of white male military generals, but of black women who lovingly change the diapers of the diseased.

Some day television companies will stop producing reality shows which delight in dysfunction, and instead offer glimpses of what liberated potentials can do.

Some day the Royal Ballet will put away the time-honoured props for Swan Lake

and appear dressed for a performance of a new heaven and a new earth.

Some day the Christian church will supplement its creeds from the distant past with covenants committing us to radical transformation.

Some day someone will write a song which begins not

'And did those feet in ancient times ...', but 'And will these feet in future years ...'.

John L. Bell

Copyright (C) 2011, Wild Goose Resource Group, Iona Community

\section{Note}

1 Drew D. Hansen, The Dream: Martin Luther King, Jr., and the Speech That Inspired a Nation (New York: Ecco, 2019). 